J. Asiat. Soc. Bangladesh, Sci. 40(2): 179-186, December 2014

\title{
FUNGI ASSOCIATED WITH COMMON SPICES IN BANGLADESH
}

\author{
TUSNIM SULTANA, SHAMIM SHAMSI AND M.A. BASHAR \\ Department of Botany, University of Dhaka, Dhaka-1000, Bangladesh
}

\begin{abstract}
Association of fungi in chili (Capsicum fruticance L.), coriander (Coriandrum sativum L.) and turmeric (Curcuma longa L.) was investigated. A total of 19 species of fungi under ten genera and one sterile mycelial fungus was isolated from the three spices. Out of ten genera three belong to Phycomycetes, one genus belongs to Ascomycetes and rest belongs to Deuteromycetes. The most frequent contaminants of the spices were Aspergillus niger van Tieghem, A. flavus Link, Fusarium nivale, Pestalotia sp. and Rhizopus sp. Dried fruits of the spices showed maximum number of fungal association in comparison with the respective commercial brand powder samples. Out of three plant extracts, A. sativum was found to inhibit the growth of all the test isolates at all concentrations.
\end{abstract}

Key words: Fungi, Spices, Bangladesh

\section{Introduction}

Fungal contamination of spices may occur when they are not properly dried or stored in a highly humid environment. The presence of fungi in spices with formation of noxious orders and other adverse effects increases the risks for mycotoxin formation under favourable condition which is harmful for consumers. Many researches has been carried out in abroad about fungal contaminants of spices (Ahene et al. 2011, Imandel and Adibenia 2000 and Stakvileviciene 2003). So far no report is available in this respect from Bangladesh.

Plant parts and their constituents of some higher plants have already been reported to be successful as fungitoxicants (Panday et al. 1983). Fungitoxicity of Allium sativum has been reported by Misra and Dixit (1977) and Ahmed and Sultana (1984). Application of plant extracts which are easily available for controlling plant diseases are non pollutive, cost effective and non hazards. On account of their non phytotoxicity and biodegradability (Fawcett and Spencer 1970) and renewable nature, such substances appear to be the ideal antifungal agents.

Considering the importance of the spices in our daily life and lack of information about the association of fungi with spices in Bangladesh, the present investigation was undertaken to detect the fungi associated with the dried fruits and dry powders of three common spices used in Bangladesh and their in vitro management. 


\section{Materials and Methods}

The materials of this investigation were the powdered spices of three different companies (Pran, Radhuni and Fresh brands) and ungrined whole of chili, coriander and turmeric, respectively. Samples were collected from Tongi market. Forty five samples of three spices were collected during the period of November, 2011 to July, 2012 and stored at room temperature $\left(19-30^{\circ} \mathrm{C}\right)$ and humidity was $60-65 \%$ before these were used for assay.

The fungi associated with the collected samples were isolated following "Tissue Planting Method"(CAB 1968). In case of intact chili and turmeric, $2^{2} \mathrm{~mm}$ size of inocula were used. In case of coriander single fruit was used as an inoculum. Inocula were washed with sterilized distilled water separately within the sterilized Petri plates. One $\mathrm{g}$ brand powder of each sample was taken in sterilized Petri plate and mixed with one $\mathrm{ml}$ sterilized water to make a paste. One loop full of ( $2 \mathrm{~mm}$ dia.) inocula was transferred on PDA medium at three points. Inoculated plates were incubated for 5 days at $25-28^{\circ} \mathrm{C}$. Percent frequency of the occurrence of the fungal isolates were calculated by adopting the formula of Spurr and Welty (1972).

Identification of the fungi was made following the standard literature (Gilman 1967, Subramanian 1971, Barnett and Hunter 1972, Booth 1971, Ellis 1971, Ellis 1976, Thom and Raper 1945, Raper et el. 1949 and Sutton 1980).

Aspergillus flavus, A. fumigatus, A. niger, Fusarium oxysporum, Curvularia lunata and Rhizopus sp. isolated from spices were selected as the test fungi. Bulbs of Allium cepa and A. sativum and tubers of Zingiber officinale were selected for screening of antifungal activity against the selected fungi. Different concentrations i.e, 5, 10,15 and $20 \%$ plant extracts were used in this study.

The toxicity of the crude plant extract was determined against the test fungi following poisoned food technique (Bashar and Raj 1991). The per cent inhibition of mycelial growth over control was calculated using the following formula:

$$
\begin{aligned}
\mathrm{I}=\frac{C-T}{C} \times 100 . & \text { Where, } \mathrm{I}=\text { Per cent growth inhibition } \\
\mathrm{C} & =\text { Growth in control } \\
\mathrm{T} & =\text { Growth in treatment. }
\end{aligned}
$$

\section{Results and Discussion}

Three common spices such as coriander, chili and turmeric powders of Fresh, Pran and Rhaduni brand companies were tested for the detection of fungi. The dried spices and powders of the brand companies and the association of fungi with the powders are presented in Plate 1. 

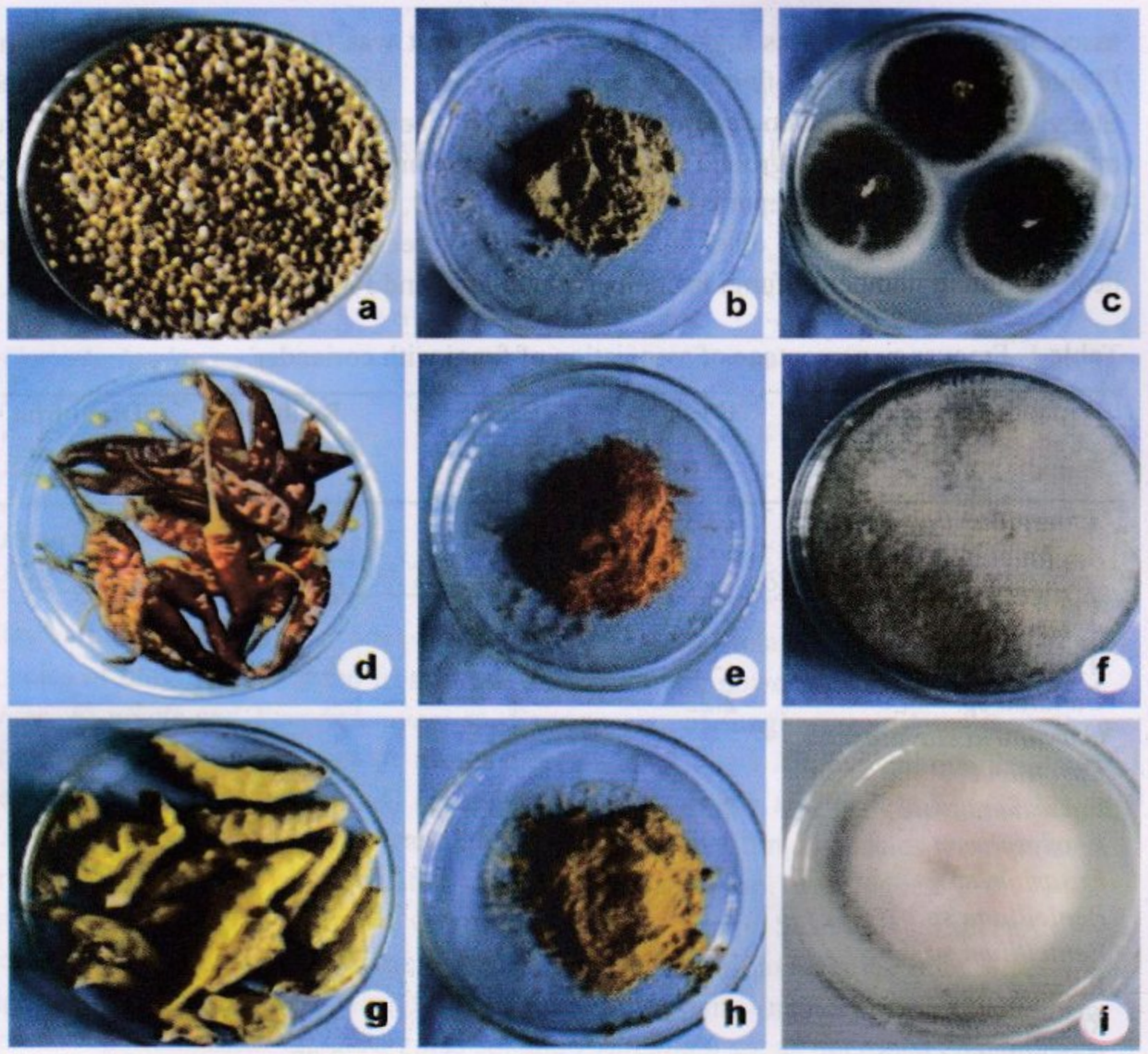

Plate 1. Different spices and fungi associated with them. a-b: Fresh fruits and powders of coriander and $\mathrm{c}$ shows the growth of Aspergillus niger. d-e: Fresh fruits and powders of chili and $\mathrm{f}$ shows the growth of Rhizopus sp. g-h: Fresh fruits and powders of turmeric and $i$ shows the growth of Fusarium nivale.

A total of 16 species of fungi belonging to eight genera and one sterile mycelium was isolated from coriander (Table 1). Seven species of fungi were associated with Fresh brand coriander powder. Frequency percentage of association of Aspergillus niger was the highest (15.55) and the lowest (2.22) was in Candida sp., F. nivale, Fusarium sp. 1 and Penicillium sp.1. Three species of fungi were isolated from Pran brand coriander powder. Frequency percentage of association of A. niger was highest (86.67) and lowest(8.89) was in A. flavus. Radhuni brand power showed eleven species of fungi. In this case Pestalotia sp. showed highest frequency percentage (33.34) and A. versicolor showed lowest frequency percentage (2.22). Ten species of fungi and one sterile mycelium were associated with fruits of coriander of which frequency percentage of 
association of $A$. niger was highest (40.75) and lowest was (1.27) in Sterile mycelium (Table 1). The present findings are in agreement with the previous reports of Stakvileviciene (2003) who reported a total of 23 species of parasitic and saprophytic micro fungi on the above ground parts of coriander. Similar observation was noticed by Ahene et al. (2011) who reported presence of A. flavus, Eurotium, Fusarium, Rhizopus and Penicillium in case of other spices. Out of the three brands Radhuni was found to bear maximum number of fungi in comparison to Pran and Fresh brands.

Table 1. Frequency percentage of association of fungi with coriander.

\begin{tabular}{lllll}
\hline Name of fungi & Fresh & $\begin{array}{l}\text { Brand } \\
\text { powder } \\
\text { Pran }\end{array}$ & Radhuni & Dried fruit \\
\hline Aspergillus flavus & 13.33 & 8.89 & 2.23 & 12.35 \\
A. glaucus & - & - & - & 3.71 \\
A. niger & 15.55 & 86.67 & 20.00 & 40.75 \\
A. terreus & 4.44 & - & - & - \\
A. versicolor & - & - & 2.22 & - \\
Candida sp. & 2.22 & - & - & - \\
Curvularia clavata & - & - & - & 3.71 \\
Eurotium sp. & - & - & 2.23 & - \\
Fusarium nivale & 2.22 & 13.33 & 33.33 & 4.94 \\
F. oxysporum & - & - & - & 18.52 \\
Fusarium sp.1 & 2.22 & - & 6.67 & 8.65 \\
Penicillium sp.1 & 2.22 & - & 13.33 & 8.65 \\
Penicillium sp. & - & - & 2.23 & - \\
Pestalotia sp. & - & - & 33.34 & 28.89 \\
Rhizopus sp. & & & 20.00 & 2.47 \\
Syncephalastrum sp. & - & - & 8.88 & - \\
Sterile Mycelia 1 & & & & 1.27 \\
\hline
\end{tabular}

Eleven species of fungi were isolated from chili of which two species of fungi were recorded from Fresh brand powder. Results presented in Table 2 show that frequency percentage of association was highest in Rhizopus sp. (97.77) and lowest was (2.23) in A. niger. Six species of fungi were isolated from Pran brand powder. Frequency percentage of association of $A$. niger was highest (53.34) and lowest was (2.23) in Rhizopus sp. From Radhuni brand powder two species of fungi were isolated of which frequency percentage of association was highest in Rhizopus sp. (62.23) and lowest in A, niger (20). Eleven fungal species were isolated from chilli fruits. Apergillus niger was the predominating (48.15) fungus while A. glaucus and Rhizopus sp. were the least (1.24) counted fungi. 
Fungi associated with common spices

Table 2. Percentage frequency of association of fungi with chilli.

\begin{tabular}{lllll}
\hline Name of fungi & Fresh & $\begin{array}{l}\text { Brand powder } \\
\text { Pran }\end{array}$ & Radhuni & Dried fruit \\
\hline Aspergillus flavus & - & 26.68 & - & 13.58 \\
A. fumigatus & - & - & - & 4.94 \\
A. glaucus & - & - & - & 1.24 \\
A. niger & 2.23 & 53.34 & 20.00 & 48.15 \\
Curvularia clavata & - & - & - & 11.12 \\
Fusarium nivale & - & 11.12 & - & 1.24 \\
F. oxysporum & - & - & - & 6.18 \\
Fusarium $\mathrm{sp} .1$ & - & 13.33 & - & 3.71 \\
Penicillium $\mathrm{sp} .1$ & - & 8.90 & - & 3.71 \\
Penicillium $\mathrm{sp} .2$ & - & - & - & 4.94 \\
Rhizopus $\mathrm{sp}$. & 97.77 & 2.23 & 62.23 & 1.24 \\
\hline
\end{tabular}

Eleven fungal species and one sterile mycelium were isolated from turmeric. Three species of fungi were isolated from Fresh brand turmeric powder. Isolated fungi were $A$. niger, F. nivale and Rhaphalomyces sp. Four species of fungi were isolated from Pran brand turmeric powder. From the results presented in Table 3 it is evident that frequency percentage of association of A. niger was highest (73.34) and lowest was (2.22) in

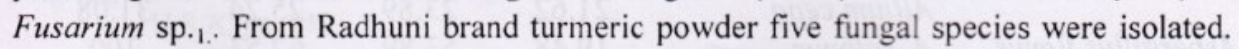
Frequency percentage of association of Syncephalestrum sp. was highest (19.99) and lowest was (6.66) in A. flavus, A. versiculor and Rhizopus sp.. Seven fungal species were isolated from rhizome of turmeric. Frequency percentage of association of $A$. niger was highest (45.69) and lowest was (1.24) in sterile mycelium. Imandel et al. (2000) from Tehran reported Mucor sp., Apergillus sp. and Penicillium sp. as microbial contaminants of turmeric and black pepper.

Table 3. Percentage frequency of association of fungi with turmeric.

\begin{tabular}{lllll}
\hline Name of fungi & Fresh & $\begin{array}{l}\text { Brand powder } \\
\text { Pran }\end{array}$ & Radhuni & $\begin{array}{l}\text { Dried } \\
\text { rhizome }\end{array}$ \\
\hline Aspergillus flavus & - & 11.12 & 6.66 & 1.24 \\
A. niger & 6.66 & 73.34 & - & 45.69 \\
A. terreus & - & - & 8.89 & - \\
A. versicolor & - & - & 6.66 & - \\
Curvularia clavata & & & & 4.94 \\
Fusarium nivale & 2.23 & 33.33 & - & 1.24 \\
F. oxysporum & - & - & - & 11.12 \\
Fusarium sp., & - & 2.22 & - & - \\
Rhizopus sp. & - & - & 6.66 & 37.04 \\
Syncephalestrum sp. & - & - & 19.99 & - \\
Rhaphalomyces & 2.23 & - & - & - \\
Sterile Mycelium & - & - & - & 1.24 \\
\hline
\end{tabular}


Effect of plant extracts on the growth of six test isolates, viz., Aspergillus flavus, A. fumigatus, A. niger, Curvularia lunata, Fusarium oxysporum and Rhizopus sp. is presented in Table 4. Although the plant extracts inhibited the growth of test isolates in most of the cases but it was found to have stimulatory effect on $C$. lunata. The inhibitory effect of the plant extracts increased with their increasing concentrations but in case of $A$. niger with Allium cepa and Fusarium oxysporum with $Z$. officinale inhibition of growth decreased with the increase of concentrations (Table 4).

The plant extracts of $A$. sativum and $Z$. officinale were found to be most inhibitory to Rhizopus sp. Both the extracts completely inhibited the growth of Rhizopus sp. The effect of $A$. sativum in all the test isolates was satisfactory followed by $Z$. officinale. The maximum inhibition of $C$. lunata was found with plant extract of $A$. sativum followed by $Z$. officinale. Out of three plant extracts, only A. sativum was found to inhibit the growth of all the test isolates at all concentrations (Table 4).

Table 4. Effects of plant extracts on the radial growth of fungi

\begin{tabular}{llcccc}
\hline Name of test fungi & \multicolumn{1}{c}{$\begin{array}{c}\text { Name of plants } \\
\text { (Treatment) }\end{array}$} & \multicolumn{4}{c}{$\begin{array}{c}\text { nhibition of growth at different } \\
\text { concentrations (\%) }\end{array}$} \\
& & 5 & 10 & 15 & 20 \\
\hline \multirow{3}{*}{ Aspergillus flavus } & Allium cepa & 21.62 & 23.89 & 25.24 & 31.08 \\
& A. sativum & 19.48 & 53.89 & 67.53 & 100 \\
& Zingiber officinale & 10.83 & 18.86 & 30.86 & 45.71 \\
A. fumigatus & Allium cepa & 22.78 & 30.10 & 37.42 & 56.93 \\
& A. sativum & 31.71 & 74.80 & 100 & 100 \\
\multirow{5}{*}{ niger } & Zingiber officinale & 16.29 & 18.73 & 52.05 & 75.61 \\
& Allium cepa & 25.36 & 24.98 & 22.01 & 14.17 \\
Curvularia lunata & A. sativum & 04.94 & 29.63 & 88.49 & 100 \\
& Zingiber officinale & 04.31 & 39.47 & 53.52 & 100 \\
& Allium cepa & +35.0 & +23.33 & +0.88 & 10.0 \\
& A. sativum & 83.88 & 100.00 & 100 & 100 \\
Fusarium & Zingiber officinale & 32.24 & 74.20 & 74.98 & 100 \\
& Allizm cepa & 36.10 & 52.24 & 56.10 & 63.34 \\
& A. sativum & 94.47 & 100 & 100 & 100 \\
Rhizopus sp. & Zingiber officinale & 61.67 & 59.44 & 45.57 & 40.00 \\
& Allium cepa & 1.08 & 3.76 & 4.84 & 8.60 \\
& A. sativum & 100 & 100 & 100 & 100 \\
& Zingiber officinale & 100 & 100 & 100 & 100 \\
\hline
\end{tabular}

Effect of plant extracts on radial growth of Curvularia lunata presented in Table 4 shows that complete inhibition of the test fungus was at $20 \%$ concentration owing to the plant extracts of $Z$. officinate and A. sativum at $10 \%$ concentration also completely inhibited the growth of the test fungus. On the other hand $A$. cepa stimulate the growth at $5-15 \%$ concentrations whereas slight inhibition was also noticed at $20 \%$ concentration (Table 4 ). 
Table 4 represents the effect of plant extracts on the radial growth of Fusarium oxysporum. Allium sativum inhibited the growth of the test fungus completely at $10-20 \%$ concentrations. The trend of inhibition of growth was also observed with $A$. cepa but in case of $Z$. officinale the inhibition decreases with increase of concentration of plant extract in culture media (Table 4).

The foregoing findings indicate that a plant extract which is inhibitory to a number of fungi may have also a stimulatory effect on other fungi. The inhibitory effect of a plant extract is owing to the presence of antifungal agents of various group like antibiotics, phenolic compounds etc (Agrios 1997). Chakraborty et al. (2004) reported the efficacy of various cell free extracts of the plants against the growth inhibition of the pathogen. The effectiveness of the extracts varied significantly with dosage, where $100 \%$ inhibition of the pathogen was achieved with garlic extract. Antifungal activity of different plant extracts have been reported earlier by several investigators against a number of plant pathogens (Monoharachary and Reddey 1978, Singh and Dwivedi 1987, Asrrafuzzaman et al. 1990, Bashar and Rai 1991).Among the three plant extracts Allium sativum was found to be most effective followed by Zingiber officinale.

\section{References}

Agrios, N. G. 1997. Plant Pathology, Fourth Edition, Academic Press, San Diago, California. U.S.A. pp. 249.

Ahene, R.E., G.T. Odamtten and E. Owusu. 2011. Fungal and bacterial contaminants of six spices products in Ghana. African Journal of Environmental Science and Technology. 5(9):633640.

Ahmed, N. and K. Sultana. 1984. Fungitoxic effect of garlic on treatment of jute seed. Bangladesh J.Bot. 13:130-136.

Asrafuzzaman, M. H., A. R. Khan and A. R. Howlider. 1990. In-vitro effect of lemon grass oil and crude extracts of some higher plants on Rhizoctonia solani. Bangladesh J. Plant Pathol. 6: 17-18.

Barnett, H. L. and B. B. Hunter 1972. Illustrated Genera of Imperfect Fungi. Burgess Publishing Company, U.S.A., Third Edition. pp. 44-45.

Bashar, M. A. and B. Rai. 1991. Antifungal activity of extracts of some plant parts against Fusarium oxysporum f. sp. ciceri. Bangladesh J. Bot. 20:219-22.

Booth, C. 1971. The genus Fusarium The Commonwealth Mycological Institute, England. pp. 155158.

CAB . 1968. Plant Pathologist's Pocket Book. The Commonwealth Mycological Institute, England. pp. 1-267.

Chakraborty,M. R. S.,S. Dutta, S. Ojha, and N. C. Chatterjee 2004. Antagonistic potential of biocontrol agents against Botryodiplodia theobromae causing die back of bottle brush (Callistemon citrinus). Acta botanica Hungarica $46: 279$-286.

Ellis, M. B. 1971. More Dematiaceous Hyphomycetes. Commonwealth Mycological Institute, England. pp. 608.

Ellis, M. B. 1976. More Dematiaceous Hyphomycetes. Commonwealth Mycological Institute, England. pp. 506. 
Fawcett, C. H. and D. M. Spencer. 1970. Plant chemotherapy with natural products. Ann. Rev. Phytopathol. $8: 403-418$

Gilman, J. C. 1976. A Manual of Soil Fungi. Oxford and IBH Publishing Co., New Delhi, Second Edition, pp. 450.

Imandel, K. and H. Adibenia 2000. Microbial contaminants of spices (turmeric, black pepper and suman) in western part of Tehran. Iranian Journal of Public Health. 29 : 1-4.

Mishra, S. B. and S. N. Dixit. 1977. Fungicidal properties of Clematis gauriana. Indian Phytopath. $30: 577-579$.

Monoharachary, C. and M. M. Reddy. 1978. Efficacy of some leaf extracts on Botrydiplodia theobromae Pat. Geobios. 5 (4): $190-191$.

Panday, D. K., H. Chandra, N. N. Tripathi and H. N. Dixit 1983. Fungitoxicity of some higher plants withspecial reference to the synergistic activity among some volatile fungitoxicants. Phytopathol. Z. $106: 226-232$.

Thom, C and K.B. Raper. 1945. A Manual of the Aspergilli. Williams \& Wilkins, Baltimore.pp. 373.

Raper, K. B. ,C. Thom and D.I. Fennel. 1949. A Manual of the Penicillia. Williams \& Wilkins, Baltimore. Pp. 875

Singh, R.K. and R. S. Dwivedi. 1987. Chemical control of Sclerotium rolfsii Sacc., a foot rot pathogen ofbarley. Nat. Acad. sci. letters 10:409-411.

Spurr, H. W. Jr. and R. E. Welty 1972. Incidence of tobacco leaf mycoflora in relation to brownspot disease and fungicidal treatment. Phytopathol. 62: 616-920.

Stakvileviciene, S. 2003. Micro fungi on above ground parts of coriander (Coriandrum sativu L.). Vagas. 58:39-42.

Subramanian, C. V. 1971. Hyphomycetes. Indian Council of Agricultural research. New Delhi.

Sutton B C 1980. The Coelomycetes, Fungi Imperfecti with Pycnidia Acervuli and Stromata. Commonwealth Mycological. Institute. UK. pp. 696.

(Received revised manuscript on 30 November 2014) 